\title{
Driving Factors and Rate of The Innovation Adoption of Sibata Carrots
}

\author{
${ }^{1}$ WINDA DESTIAMAYU, ${ }^{2}$ MAHRA ARARI HERYANTO \\ ${ }_{1,2}^{2}$ Fakultas Pertanian, Universitas Padjadjaran, JI.Raya Bandung Sumedang Km.21 Jatinangor 45363 \\ Email: ${ }^{1}$ destiamayuwinda@gmail.com; ${ }^{2}$ mahra.arari@unpad.ac.id
}

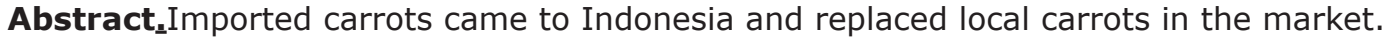
Demand of imported carrot quality was fulfilled by Katata farmer group through institutional innovation such as seed application, plant space arrangement, and harvest pattern management. According to the farmers' behaviors which are difficult to adopt the innovation, it is necessary to identify the driving factors of innovation rate in carrot cultivation. The objectives of this paper are to identify how fast the innovation adoption rate of the farmer and the driving factors of Sibata carrot cultivation rate. This paper is quantitative research design using Rank Spearman correlation. The result showed that there are 11 of 20 driving factors that push the Sibata carrot cultivation rate, which are economic benefit, quality benefit, innovation trialability, innovation observability, income, information source, input services quality, supervision, farmer-supervisor communication, price guarantee, and market guarantee. Social, economic, and technological aspect are simultaneously having a significant relationship in determining the adoption rate.
\end{abstract}

Keyword: Adoption, Innovation, Driving Factor, Sibata Carrot

\section{Introduction}

Imported carrots in Indonesia have impacted on the availability of two options upon carrot commodities for consumers. According to the quality, imported carrots are good in appearance: they are similar in shape, bright in color, and less in water content, meaning they are not easy to rot. These superiorities inspired Katata Farming Group to develop local carrots that resembled to imported carrots. This Katata Farming Group focuses on producing good quality vegetable in Bandung. Their products are distributed to the modern retails around Bandung and Jakarta which are the members of Hero Group.

One of the best commodities produced by this group is Sibata carrot. This carrot was firstly inspired by Sibayak carrot from North Sumatera. The quality of carrots produced in Sibayak area resembles the quality of imported carrots. Katata Farming Group tried to develop their version of carrot seeds until they finally succeeded to make carrot seeds with quality close to the imported carrot seeds. This seed was named "Sibata" which is the abbreviation of the words "Sibayak Katata".
The quality of Sibayak carrots, which is similar enough to the quality of imported carrots, is hugely demanded by modern retails. Katata Farming Group then tried to fulfill that demand through engineering innovation. Since the "green revolution" in Indonesia was started in 1970s, agricultural development has been focusing more on improving intensification quality which pursued through the application of innovation, both technical and social innovations. Therefore, the study of the innovation adoption is essential to be done (Harinta, 2011).

The new variety of carrot derived from the variety of Sibayak carrot is such an innovation in the cultivation of carrot in Bandung Regency. Together with Universitas Padjadjaran, the Local Government of Bandung Regency, Bank Indonesia, and Hero Group, Katata Farming Group developed a new variety of carrot with physical characteristics resembled the Sibayak carrot.

The development of this variety of carrot included the use of the seeds produced from tissue culture, ordering the planting distance, as well as ordering the harvesting pattern. Rogers and Shoemakers (1987) defined innovation as new ideas, new

Received: 03 July, 2017, Revision: March 30, 2017, Accepted: May 19, 2017

Print ISSN: 0215-8175; Online ISSN: 2303-2499. DOI: http://dx.doi.org/10.29313/mimbar.v33i2.2674.370-377

Accredited B based on the decree No.040/P/2014, valid on February, 18, 2014 until February, 18, 2019. Indexed by DOAJ, Sinta, IPI 
practices, or objects seemed as something new by individual or society. The process of behavior shift in knowledge, attitude, and skill in one's self after accepting innovation is called adoption. The acceptance meant here is not only knowing the innovation, but also applying it correctly as well as comprehending it in the life of farming.

During the innovation adoption process, the members of Katata Farming Group could not accept the innovation directly. Few of them hesitated to apply the innovation because they were accustomed to the cultivation technics of local carrots. Due to their doubt, the observation on the factors that could encourage them to adopt the innovation of Sibata carrot cultivation was needed. It was important because it aimed to improve their welfare as well as the agricultural development. Development can be defined as a conscious and planned effort to implement changes that lead to economic growth and the quality of life improvement or welfare of all citizens in a long-term by using the chosen technology (Mardikanto, 1996).

Prabayanti (2010) states that adoption is a process experienced by farmers until they finally decide whether or not to apply the innovation. Their decision to apply the innovation or not determined by many factors. According to the previous statements, this research aims to (1) know the rate of the farmers in adopting the innovation of Sibata carrot cultivation and (2) to know the factors that encourage the rate of the innovation adoption of Sibata carrot cultivation.

\section{Methodology Research}

This research was conducted by using quantitative design with a case approach. The observation was done at Katata Farming Group, Margamekar Village, Pangalengan Subdistrict, Bandung Regency. The farming group criterion in this observation was that the group that had cultivated the carrots which resembled the imported carrots.

This research was done by surveying all the farmers in Katata Farming Group that were planting carrots, all are 23 people. The data were collected through questionnaire, site observation, and documentation studies. The data were analyzed by using descriptive approach and Rank Spearman's correlation.

The driving factors that were tested in the process of innovation adoption consisted of 20 factors and their connection with the innovation adoption rate of Sibata carrot cultivation would be observed. The factors included economic benefit, quality benefit, quantity benefit, suitability, complexity, trialability, observability, age, education level, land area, income level, participation in group level, information source, input service quality, supervision, the farmer and the supervisor communication, price guarantee, price conformity, payment timeliness, and market guarantee.

Katata Farming Group was established in December 9, 2009. Katata in Sundanese language means "manageable" ( $k a$ tata $=k a$ atur=to-be-able to manage). The name was coined together with the hope that the farmers in Katata Farming Group would be able to manage themselves in overcoming current agricultural situation. At first the group consisted of 6 farmers who were aware of the importance of grouping in farming and were sensitive with the agricultural information and development. Today Katata group has 125 members and 12 group coordinators. This farming grouping was the result of the farmers' discussion about the uncertainty of vegetable price. It was then followed by their visits to the agricultural centers including to some modern retails with the aim of looking for the information about horticultural agriculture market opportunity, especially vegetable.

The commodities cultivated in the group are baby Kenya bean, radish, local tomato or TW tomato, beef tomato, cherry tomato, Sibata carrot variety as well as its seedling, and granola potato and its seedling.

\section{Sibata Carrots}

The demand of the carrots which their quality resembled the imported ones are very high. It is about 10 tons per day. Nevertheless, until today, Katata Farming Group can only fulfill the demand of 2 tons per week. The marketed Sibata carrots consist of two kinds: regular Sibata and baby Sibata. The required specifications for the carrots are bright and evenly distributed color (brick orange color), smooth, and similar in shape. The shape of Sibata carrots are divided into two kinds: regular and baby carrots. The regular one has the length of $15-25 \mathrm{~cm}$ (4-6 carrots per $\mathrm{kg}$ ) and is sold at Rp3,500.00, while baby carrot has the length of $10-15 \mathrm{~cm}$ (8-12 carrots per $\mathrm{kg}$ ) and is sold at Rp5,000.00. 
The carrot seeds are provided by the farming group to fulfill the need of the farmers. The term of planting distance determined by Katata Farming Group is $15 \times 20 \mathrm{~cm}$, where every hole is filled with 3-5 carrot seeds. This method is considered efficient because the use of the required seeds become more managed and more economic.

\section{The Innovation Adoption Rate of Si- bata Carrot Cultivation}

Rogers and Shoemakers (1987) define innovation as new ideas, new practices, or objects seemed as something new by individual or society. According to Mardikanto (2002), the stages of innovation adoption can be a tool to measure the rate of innovation adoption. There are five stages of innovation adoption: awareness, interest, evaluation, trial, and adoption. The rate of innovation adoption is the speed level at which participants adopt an innovation.

The innovation adoption rate in the cultivation of Sibata carrots can be seen in the table below.

\section{Table 1}

The Innovation Adoption Rate of Sibata Carrot Cultivation by the Farmers

\begin{tabular}{ccc}
\hline Category & $\begin{array}{c}\text { Frequency } \\
\text { (individuals) }\end{array}$ & $\begin{array}{c}\text { Percentage } \\
(\%)\end{array}$ \\
\hline $\begin{array}{c}\text { Fast } \\
(3-4 \text { months })\end{array}$ & 18 & 78 \\
$\begin{array}{c}\text { Medium } \\
(5 \text { months })\end{array}$ & 2 & 9 \\
$\begin{array}{c}\text { Slow } \\
(>5 \text { months })\end{array}$ & 3 & 13 \\
Total & 23 & 100 \\
\hline
\end{tabular}

The innovation adoption rate of the farmers who had applied the innovation in Sibata carrot cultivation is in the fast category. The interviews with the farmers resulted in the data about the farmers' interval of knowing until applying the innovation. $78 \%$ of the farmers were in the fast category in doing the innovation adoption. This was due to their interest in adopting the innovation to be able to produce the carrots with the quality resembled the imported ones so that the demand would be higher. Moreover, they felt that the innovation could be initially observed and tried. After knowing the innovation, they followed the next steps until the carrots could be harvested. After getting the result, $78 \%$ of the farmers immediately applied the cultivation innovation on the carrots. On the other hand, the percentage of the medium category was $9 \%$. The farmers who were included in this category were those who did not directly adopt the innovation. They were still encouraged to be sure that the innovation would give them benefits. The last category was the slowest one that reached $13 \%$. They also needed to be encouraged by showing them the process two times as well as the results. After looking more than one time, they were convinced and adopted the innovation.

In adopting the Sibata carrot cultivation innovation, the farmers who planted carrots were classified into the early majority group. According to Rogers (1995), this early majority group is the group that accepts the innovation as long as it provides benefits. The decision to accept the adoption is considered carefully because the failure in applying the innovation impacts upon the farmers' life. In the matter of Sibata carrots, the innovation gave them benefits so that they could accept it.

The adoption innovation rate of Sibata carrot cultivation could be seen by measuring the interval from the awareness stage to the adoption stage. The interval had to include the fast category. The rate of Sibata carrot farmers at Katata Farming Group in knowing the innovation until adopting it was mostly around 3 to 4 months.

\section{The Driving Factors of The Innova- tion Adoption Rate In Sibata Carrot Cultivation}

According to the results, among 20 factors mentioned above, there were 11 significant factors in the innovation adoption rate of Sibata carrot cultivation and 9 factors that did not relate to it. Those 11 factors were economic benefit, quality benefit, trialability, observability, income level, information source, input service quality, supervision, the farmer and the supervisor communication, price guarantee, and market guarantee. On the other hand, the remaining 9 factors were quantity benefit, suitability, complexity, age, education level, land area, participation in group level, price conformity, and payment timeliness.

After knowing which factors significantly related to the innovation adoption rate of Sibata carrot cultivation, the factors with positive values would be seen. They are factors that drove the adoption rate of an 
innovation and have strength values which can be seen as well.

The direction and the correlation strengths between the factors and the innovation adoption rate of Sibata carrot cultivation are shown below.

Table 2

The Driving Factors of the Innovation Adoption Rate

\begin{tabular}{cccc}
\hline Factors & $\begin{array}{c}\text { p-val- } \\
\text { ues }\end{array}$ & $\begin{array}{c}\text { Correlation } \\
\text { Coefficients }\end{array}$ & $\begin{array}{c}\text { Relation } \\
\text { Strengths }\end{array}$ \\
\hline Innovation & 0.000 & 0.742 & Strong \\
observability & 0.047 & 0.733 & Strong \\
Income level & 0.002 & 0.674 & Strong \\
Quality ben- & 0.001 & 0.630 & Strong \\
efit & 0.004 & 0.579 & Strong \\
Economic & & & \\
benefit & 0.008 & 0.539 & Strong \\
Farmer and & 0.007 & 0.533 & Strong \\
supervisor & 0.007 & 0.516 & Strong \\
communica- & 0.018 & 0.489 & Medium \\
tion & 0.028 & 0.459 & Medium \\
Supervision & 0.045 & 0.422 & Medium \\
Price guaran- & & & \\
tee & & & \\
Information & & & \\
source & & & \\
Innovation & & & \\
trialability & & & \\
Market guar- & & & \\
antee & & & \\
Input service & & & \\
quality & & & \\
\hline
\end{tabular}

The factors that related to the innovation adoption rate of Sibata carrot cultivation were dominated by those that had strong relations. It can be seen from the table that the lowest value of correlation coefficients on the innovation adoption driving factors was 0.422 , which meant there was no weak factor of correlation coefficients. On the other hand, some factors did not relate to the innovation adoption because of the weak relation strength tendency. The factors that did not relate to the innovation adoption rate of the farmers in Sibata carrot cultivation are shown below.

Table 3

The Factors that Did Not Relate to the Innovation Adoption Rate

\begin{tabular}{|c|c|c|c|}
\hline Factors & $\begin{array}{c}\text { p-val- } \\
\text { ues }\end{array}$ & $\begin{array}{l}\text { Correlation } \\
\text { Coefficients }\end{array}$ & $\begin{array}{l}\text { Relation } \\
\text { Strengths }\end{array}$ \\
\hline $\begin{array}{c}\text { Innovation } \\
\text { suitability }\end{array}$ & 0.637 & 0.364 & Medium \\
\hline Land area & 0.109 & 0.343 & Medium \\
\hline
\end{tabular}

\begin{tabular}{|c|c|c|c|}
\hline Factors & $\begin{array}{l}\text { p-val- } \\
\text { ues }\end{array}$ & $\begin{array}{l}\text { Correlation } \\
\text { Coefficients }\end{array}$ & $\begin{array}{l}\text { Relation } \\
\text { Strengths }\end{array}$ \\
\hline $\begin{array}{l}\text { Quantity } \\
\text { benefit }\end{array}$ & 0.114 & 0.339 & Medium \\
\hline $\begin{array}{l}\text { Participation } \\
\text { in group }\end{array}$ & 0.128 & 0.328 & Medium \\
\hline $\begin{array}{l}\text { Innovation } \\
\text { complexity }\end{array}$ & 0.132 & 0.323 & Medium \\
\hline $\begin{array}{l}\text { Payment } \\
\text { timeliness }\end{array}$ & 0.552 & 0.131 & Weak \\
\hline Age & 0.517 & 0.125 & Weak \\
\hline $\begin{array}{c}\text { Price } \\
\text { conformity }\end{array}$ & 0.637 & 0.104 & Weak \\
\hline $\begin{array}{c}\text { Education } \\
\text { level }\end{array}$ & 0.747 & 0.071 & Weak \\
\hline
\end{tabular}

It can be seen from the table above that the factors which did not have any correlations tended to have low values in the correlation coefficients. Even though some factors were in the medium category, they still tended to be weak. Medium category means that the correlation coefficients are between the strong category and the weak category. Nevertheless, medium category tended to be included in the weak relation. Those weak relations in some factors have the $p$-values of more than 0.05 , which meant there were no relations at all. Those factors also did not related because they had no same opportunities in the innovation adoption rate.

\section{The Factors That Had Strong Rela- tions with The Innovation Adoption Rate Of Sibata Carrot Cultivation}

According to the tables, there are 8 factors that have strong relations as well as drive the innovation adoption rate of Sibata carrot cultivation. They are innovation observability, income level, relative benefit from the quality aspect, relative benefit from the economic aspect, farmer and supervisor communication, supervision, price guarantee, and information source. The following explanations are about the strong relations of the factors with the innovation adoption rate.

\section{Innovation Observability}

The correlation coefficient of the innovation observability was 0.742 . It proved that the innovation observability drove the innovation adoption rate of Sibata carrot cultivation. It could not be denied that before applying the innovation adoption, the farmers had to initially look at the innovation. They would observe whether the innovation would 
give them benefit or not. By observing the process of the cultivation, they would judge if the innovation was good or not. As it is explained before, the farmers would follow an innovation if the innovation can initially be observed because the observation is the most important thing in their decision making. The observation is the time for farmers to see whether the innovation is good or not. Thus, observability had a strong relation with the farmers' rate in adopting the innovation of Sibata carrot cultivation.

\section{Income Level}

The correlation coefficient of the income level was 0.733 . It had a strong relationship and drove the innovation adoption rate of Sibata carrot cultivation. Averagely, the farmers were in the high income category. The higher their income, the faster they adopted the innovation. Besides, they were not afraid to adopt the innovation because they had high capital to try another new farming project. Therefore, income level had a strong relation with the innovation adoption of Sibata carrot cultivation.

\section{Quality Benefit}

The correlation coefficient of the quality benefit factor was 0.674 . It can be assumed that the quality benefit drove the innovation adoption rate of Sibata carrot cultivation. The innovation given to the carrots made their quality resembled the imported carrots. The qualities that were applied made them similar in shape, interesting in color (orange brick color), and sweet in taste. The innovation given to the Sibata carrot cultivation made them demanded in modern markets. Besides, the quality benefit had a strong relation with the innovation adoption of Sibata carrot cultivation due to the farmers' hope to make Katata Farming Group the pioneer of farmers' who cultivated carrots with import quality. They hoped that the resemblance of the carrots with the imported ones would make other farmers grow them and adopt the innovation. The better the quality resulted, the stronger the relation of the factor with the innovation adoption of Sibata carrot cultivation was.

\section{Economic Benefit}

The correlation coefficient of the economic benefit factor was 0.630 . This coefficient drove the innovation adoption rate of Sibata carrot cultivation and had a strong relation. It was because carrots gave benefits to the farmers' economy. Even though the cost of cultivating Sibata carrots was more than that of the local, the sale profits were still in their calculation. They thought that the good quality carrots brought more profits to their economic life. Something should be known is that the innovation in Sibata carrot cultivation makes the carrots' price remain stable even in the rainy season. Other carrots become relatively cheap while Sibata carrots will be stable. Moreover, the seeds that are needed to grow Sibata carrots are less than those needed to grow other carrots because the farmers use planting distance method, not by spreading the seeds. Even though the planting process needs more cost to pay the employees, the results are profitable. If the farmers do not use planting distance method, the weeding of weeds has to be done three times, but by using planting distance method, the weeding is only done one time. The more profitable the economic benefit, the stronger the relation of the factor with the innovation adoption of Sibata carrot cultivation would be.

\section{Farmer and Supervisor Communication}

The correlation coefficient of the communication among the farmers and the supervisors was 0.579 . The coefficient showed that communication had a strong relation as well as drove the innovation adoption rate of Sibata carrot cultivation. The supervisors in the farming group were always in a good communication with the farmers. They developed the communication by asking whether there were problems happened, what things had been done by the farmers, and other matters related to the farming activities. Then, they held group meetings at least once a week to evaluate and report the accomplishment they had achieved in a week. This communication had a strong relation with the innovation adoption rate of Sibata carrot cultivation because by developing the communication, the farmers would understand more about the benefits of the innovation applied as well as the profits they would get. Furthermore, by doing some good communication, the farmers and the supervisors could share their experience and solve various problems together. The better communication developed among the farmers and the supervisors, the stronger the relation of the factor with the innovation adoption rate of Sibata carrot cultivation would be. 


\section{Supervision}

The correlation coefficient of the supervision factor was 0.539 which showed its contribution to the strong relation and drove the innovation adoption rate of Sibata carrot cultivation. The supervision in Katata Farming Group was done once a week by the supervisors and valued good. They directly supervised the situation in the site, the group meetings, otherwise they would did it via telephone, short messages, and social media. The better the supervision done, the stronger the relation of the factor with the innovation adoption rate of Sibata carrot cultivation would be.

\section{Price Guarantee}

The correlation coefficient of the price guarantee factor was 0.533 . The coefficient showed that this factor had a strong relation and drove the innovation adoption rate of Sibata carrot cultivation. Katata Farming Group had guaranteed the price of carrot products. It was impossible to decrease while other carrots'prices in the markets could dropped dramatically, even to Rp5,00.00/ $\mathrm{kg}$. The price of Sibata carrots would remain the same in various conditions, both in high and low season. This Katata Farming Group's guarantee made the farmers did not afraid of the sudden price reduction, especially when the prices decreased. It made the factor of price guarantee have a strong relation with the innovation adoption rate of Sibata carrot cultivation.

The price transparency built by the group fosters their mutual trust among members. Structured price guarantee in the market motivates the farmers to supply their vegetable products to the group, including Sibata carrots (Andayani, et al.,2016). The farmers are benefited by this price guarantee.

\section{Information Source}

The correlation coefficient of the information source factor was 0.516 . The coefficient of this factor had a strong relation and drove the innovation adoption rate of Sibata carrot cultivation. The information source had the strong relation because it gave information about the innovation of Sibata carrot cultivation. The farmers used at least two sources of information about the innovation of the cultivation. They were included the innovative farmers if they used more than one source. It has been known that innovative people will be faster in adopting the innovation; thus, the information source factor had a strong relation with the farmers' rate in adopting the innovation of Sibata carrot cultivation.

\section{The Factors That Had Medium Rela- tion with The Innovation Adoption Rate Of Sibata Carrot Cultivation}

According to the tables, it is known that 3 factors have medium relation and drive the innovation adoption rate of Sibata carrot cultivation. They are innovation trialability, market guarantee, and input service quality. The explanations below are about the relation of the factors with the innovation adoption rate.

\section{Innovation Trialability}

The correlation coefficient of the innovation trialability was 0.489 . It showed that this factor had a medium relation and drove the innovation adoption rate of Sibata carrot cultivation. An innovation will be fast adopted if it is initially tried in a small scale or in other people's area. The medium relation of the innovation trialability meant that the relation between the innovation trialability and the adoption rate was weak. This was because the most important process in the innovation characteristic is observability. The farmers try the innovation given, but they have to be more observable to see whether or not the innovation is good. Thus, the innovation trialability had a relation with the innovation adoption rate, but the relation was medium because the stronger one existed when the innovation was observed.

The innovation trialability is a real form in the application of agricultural science and technology. Itis something that encourages the entrepreneurial soul of people in the countrysides. If there is a stagnation of this application, the entrepreneurial innovation will not develop (stagnant) (Setiawan, et al., 2015).

\section{Market Guarantee}

The correlation coefficient of the market guarantee factor was 0.459 . It showed that this factor had a medium relation and drove the innovation adoption rate of Sibata carrot cultivation. It had a medium relation because 
Katata Farming Group provided certain markets for the supply of Sibata carrots. Nevertheless, it is known that the markets' demand for Sibata carrots is high and reaches 10 tons per day. There were many markets that wanted the carrots, so it was not difficult to market them. Besides, the farmers tended to see the price guarantee in adopting the innovation of Sibata carrot cultivation. Thus, the market guarantee factor in Katata Farming Group had a medium relation with the farmers' rate in adopting the innovation of Sibata carrot cultivation.

\section{Input Service Quality}

The correlation coefficient of the input service quality factor was 0.422 . The coefficient showed that the factor had a medium relation and drove the innovation adoption rate of Sibata carrot cultivation. The input service quality in Katata Farming Group was seeds. They were directly bought by the farmers who grew Sibata carrots from the head of the group. The input service quality had a medium relation because the quality given had been good but it was not a strong factor that made the farmers adopt the innovation of Sibata carrot cultivation. The input service quality was only the addition value of the reason they applied the innovation adoption of Sibata carrots cultivation.

\section{Conclusions}

The farmers' rate in adopting the innovation of Sibata carrot cultivation was averagely taken about 3-4 months. It meant that they only required to see one carrots' growing season and immediately adopted the innovation of Sibata carrots cultivation. There were 11 out of 20 factors that significantly drove the innovation adoption rate of Sibata carrot cultivation. The factors that had strong relations with the innovation adoption consisted of 8 factors. They were the innovation observability, income level, quality benefit, economic benefit, farmer and supervisor communication, supervision, price guarantee, and information source. Meanwhile, there were 3 factors that had medium relations with the innovation adoption. They were the innovation trialability, market guarantee, and input service quality.

Related to the process of the innovation adoption, the adoption introduced to Katata Farming Group in this research was the optional and collective decision. In the optional and collective decision, economic aspect is dominant in determining the adoption decision. The technology innovation in Sibata carrots had to be accompanied by the institutional innovations which could be done through the input service quality and the interaction among the farmers and the supervisors (Heryanto, et al., 2016; Hakim dan Perdana, 2017).

This kind of pattern can be replicated by the same social and environmental characteristics through the development of demonstration plot in the innovation of carrot cultivation. It is by the cultivation trial so that the farmers can observe the innovation. By doing it, the information will widely spread and the innovation can be offered to other farmers in Katata Farming Group. Besides, the farming group will give more variations to the input service facilities. The only input in Katata Farming Group today is the service in seeds. Meanwhile, the farmers need other input facilities like fertilizers, pesticides, and other farming tools to get good and similar quality.

\section{Acknowledgement}

We would like to thank Ministry of Research, Technology, and Higher Education of the Republic Indonesia and Universitas Padjadjaran that founded the National Prime Strategic Research (Penelitian Unggulan Strategis Nasional/Pusnas) with the title "Development of High Value Agribusiness Cluster to Increase The Competitiveness and Farmer Income Through Science, Technology and Social Engineering and Market Oriented" in year 2017.

\section{References}

Andayani, S.A., Sulistyowati, L. and Perdana, T., (2016). The Development Of Red Chili Agribusiness Cluster With Soft System Methodology (Ssm) Approach In Garut, West Java. MIMBAR, Jurnal Sosial dan Pembangunan, 32(2), pp.302-310.

Hakim, L. and Perdana, T., (2017). System Dynamics Modeling on Integrated Supply Chain Management of Potato Agribusiness. MIMBAR, Jurnal Sosial dan Pembangunan, 33(1).

Harinta, Yos Wahyu. (2011). ISSN: 14100029 Agrin Vol. 15, No. 2, Oktober 2011: Adopsi Inovasi Pertanian di Kalangan 
Petani di Kecamatan Gatak Kabupaten Sukoharjo. jurnal.faperta.unsoed.ac.id accessed on a date 11 February 2017

Heryanto, M.A., Sukayat, Y. and Supyandi, D., (2016). Model Perilaku Petani Dalam Adopsi Sistem Usahatani Padi Organik: Paradoks Sosial-Ekonomi-Lingkungan. Sosiohumaniora, 18(2).

Mardikanto, T. (1996). Penyuluhan, Pembangunan Kehutanan. Departemen Kehutanan, Jakarta.

Mardikanto, T. (2002), Komunikasi Pembangunan. UNS Press Surakarta.

Prabayanti, Herning. (2010). Faktor-Faktor yang Mempengaruhi Adopsi Biopestisida oleh Petani di Kecamatan Mojogedang
Kabupaten Karang Anyar. https://digilib. uns.ac.id accessed on a date 11 February 2017

Rogers EM. dan Shoemekers F. Comunication of Inovation, Terjemahan oleh Hanafi A., (1987). Memasyarakatkan Ide-ide Baru. Surabaya: Usana Offset Printing.

Rogers E.M. (1995). Diffusion of Innovations. The New York: Free Press.

Setiawan, I., Sumardjo, S., Satria, A. and Tjitropranoto, P., (2015). Strategi Pengembangan Kemandirian Pelaku Muda Agribisnis "Brain Gain Actors" di Jawa Barat. MIMBAR, Jurnal Sosial dan Pembangunan, 31(2), pp.409-418. 